\title{
ERISA Confronts ESG
}

\author{
David D. Schein \\ University of St. Thomas
}

\begin{abstract}
Environmental, Social and Governmental issues, ("ESG"), has been paired with "Human Capital" issues in a sweeping movement that has progressed from university theories to the board rooms of some of the world's biggest corporations over the last decade. There has also been a rapid growth of investments funds that advertise consideration of ESG and related issues. A practical question is whether employee benefit plans that are subject to strict regulations under the federal law known as ERISA can incorporate ESG considerations in selecting investments for these plans. At present, there is a distinct split of authority due to conflicting rules by the US Department of Labor. This paper will explore some of the key issues regarding ERISA and ESG.
\end{abstract}

Keywords: ERISA, ESG, compliance, investments, advisors, USDO

\section{INTRODUCTION}

Environmental, Social and Governmental issues, ("ESG"), has been paired with "Human Capital" issues in a sweeping movement that has progressed from university theories to the board rooms of some of the world's biggest corporations over the last decade (Zweig, 2021). There has also been a rapid growth of investments funds that advertise consideration of ESG and related issues (Gurdus, 2021). A practical question is whether employee benefit plans that are subject to strict regulations under the federal law known as ERISA (Employee Retirement Income Security Act, 1974) can incorporate ESG considerations in selecting investments for these plans (Fifth Third Bancorp v. Dudenhoeffer, 2014). Late in 2020, the US Department of Labor ruled that ERISA qualified plans could only consider financial issues when determining suitable plan investments (Financial Factors in Selecting Plan Investments, 2020). The incoming Biden administration has suspended enforcement of the Trump era rule, but has not yet modified the rule. This paper will explore some of the key issues regarding ERISA and ESG at this time.

\section{INVESTMENTS UNDER ERISA}

ERISA was passed in 1974 to remedy a dramatic situation that occurred a decade earlier when the Studebaker-Packard Corporation closed its last American manufacturing plant (Wooten, 2001). The headlines resulted when the former employees sought their pension benefits which had been earned by them pursuant to their various union contracts. These former employees discovered that Studebaker-Packard management had underfunded the employee pension plan, which gave the company more working capital, but not enough to keep it afloat (Wooten, 2001). The older employees did receive pensions, but thousands of employees, including all of the employees who were under 40 years old, received no pension benefits at 
all (Wooten, 2001). In one of the mysteries of the American legislative system, it took a decade to create and enact one of the most complicated Federal laws of the last century (Wooten, 2001, p. 739). The objective of ERISA was to simply provide that employers may not underfund their employee pension plans and that promised benefits need to be there when employees retire. To achieve these ends, strong fiduciary rules were established that pushed managers of these ERISA plans into conservative investments (Oringer et al., 2020). The rules of ERISA investing were recently summarized as:

Section 404 of ERISA, in part, requires that plan fiduciaries act prudently and diversify plan investments so as to minimize the risk of large losses, unless under the circumstances it is clearly prudent not to do so. Sections 403(c) and 404(a) also require fiduciaries to act solely in the interest of the plan's participants and beneficiaries, and for the exclusive purpose of providing benefits to participants and beneficiaries and defraying reasonable expenses of administering the plan (Financial Factors in Selecting Plan Investments, 2020).

\section{Responsibility of ERISA Plan Administrators}

ERISA states that plan fiduciaries act "for the exclusive purpose of: (i) providing benefits to participants and their beneficiaries; and (ii) defraying reasonable expenses of administering the plan (Employee Retirement Income Security Act, 1974)." Challenges to administration of covered plans were generally not successful in the past. Kulesza v. N.Y Univ. Med. Ctr. is a typical ERISA case where the plaintiff plan participants were denied further consideration of their complaints against the plan administrator even though it appeared that they had a solid case against the administrator (2001). The court allowed state law claims to continue, but due to the ERISA preemption, such claims often do not present much of a opportunity for success for the plaintiffs. In a similar vein, most of the plaintiffs' case was dismissed in Loren v. Blue Cross \& Blue Shield, but a part of the case was allowed to continue under a technical reading of the ERISA statute (2007). This case illustrates the difficulty of attempting to enforce claims under ERISA-qualified plans in the past. Another reported case decided prior to 2010 which underscored the complexity of ERISA litigation and sorting out state law claims as opposed to federal claims under ERISA is McLeod Reg'l Med. Ctr. v. Trustmark Life Ins. Co (2010). The state law breach of contract claim was allowed to proceed since the court determined that the contract in question was operative outside of ERISA plan documents. Other claims of the plaintiffs were dismissed pursuant to ERISA (McLeod Regional Medical Center v. Trustmark Life Insurance Company, 2010).

A potential change in claims alleging breach of fiduciary duties by ERISA plan administrators was brought about in the 2011 US Supreme Court decision in CIGNA Corp. v. Amara. CIGNA converted its traditional employee pension plan that paid on an annuity basis and converted it to a cash benefit plan. In doing so, persons who were already eligible for some pension benefits alleged that they would receive less under the replacement plan than their individual plan benefits were worth at the time of the conversion. Specifically, the plaintiffs claimed that the description provided to them about the conversion deceptively valued the cash balance at less than the employees should have received. The Supreme Court went on to recognize the award of "equitable relief" to the plaintiffs in such cases (CIGNA Corp. v. Amara, 2011).

In a 2017 article, the authors summarized the ERISA case law following the Amara decision, analyzing the impact on awards for the plaintiffs since the 2011 decision (Martin \& Amert). The article noted a factually similar 2017 case of Osberg v. Foot Locker, Inc. from the Second Circuit Court of Appeals with a comparable ruling for the plaintiffs. The article also noted cases from the Fourth and Sixth Circuits recognizing expanded equitable remedies such as surcharge and estoppel (Martin \& Amert, 2017). The issue then arises that with the potential expansion of equitable remedies whether ERISA plan fiduciaries should decline to consider ESG issues, or, incorporate ESG issues, in making investment decisions.

The key statement from the Supreme Court on the responsibility of plan administrators with regard to pecuniary as opposed to other considerations is:

"Read in the context of ERISA as a whole, the term 'benefits' in the provision just quoted must be understood to refer to the sort of financial benefits (such as retirement income) 
that trustees who manage investments typically seek to secure for the trust's beneficiaries." And, "The term does not cover nonpecuniary benefits like those supposed to arise from employee ownership of employer stock (Fifth Third Bancorp v. Dudenhoeffer, 2014, p. 421)."

So while plan beneficiaries may be able to seek greater recoveries from plan administrators, they may not be able to seek such relief to require ESG considerations in investment decisions.

\section{Relying on Material Information for Investment Decisions}

A key consideration for ERISA plan administrators is that they should rely on "material information" related to their investment decisions. The Securities and Exchange Commission ("SEC") has provided guidance on the subject of financial materiality (U. S. Securities and Exchange Commission, 1999). As noted above, the critical aspect of this relating back to the Studebaker bankruptcy is that by appropriate and conservative investment decisions, the funds placed in the ERISA qualified benefits plans actually will have the resources to pay the promised benefits as the demand occurs.

The challenge of incorporating ESG considerations into ERISA plan investments directly impacts the issue of materiality. This was highlighted by SEC Commissioner Hester M. Peirce in her Public Statement (2020). She stated that: "The concept of materiality has worked well over time because it considers disclosure through the prism of the reasonable investor, who is occupied with the long-term financial value of the enterprises in which she invests (Peirce, 2020)." Peirce then tied her concerns to consideration of ESG when she stated: "There is reason to question the materiality of ESG and sustainability disclosure based on existing practices (2020)." She also noted that there are no consistent reporting standards with regard to the elements of ESG at this time. In fact, the SEC issued a Risk Alert in April 2021 to caution investors regarding the uncertainty surrounding the use of ESG material provided by public companies. The Alert stated:

This rapid growth in demand, increasing number of ESG products and services, and lack of standardized and precise ESG definitions present certain risks. For instance, the variability and imprecision of industry ESG definitions and terms can create confusion among investors if investment advisers and funds have not clearly and consistently articulated how they define ESG and how they use ESG-related terms, especially when offering products or services to retail investors (U. S. Securities and Exchange Commission, 2021a).

In fact, the SEC has a link to several reports regarding consideration of ESG, and with an emphasis on climate change (U. S. Securities and Exchange Commission, 2021b). These reports specifically note the movement toward ESG considerations since 2010, but express the concern that there is still not enough consistency in the information utilized and the explanations for investors (U. S. Securities and Exchange Commission, 2021b).

\section{AVAILABLE ESG INVESTMENT INFORMATION}

In its most recent release of information about ESG considerations in investing, the Asset Management Advisory Committee of the SEC released a "Discussion Draft" of its recommendations for moving forward (2021). The Draft begins with the rather sober observation that there is still no consistent reporting available for investors to evaluate the different components of ESG. It adds that each letter in ESG stands for a significant area of concern with multiple factors for evaluation of each area. The Draft authors expressed concern that because of the lack of hard data to compare various factors, some investors may fall prey to "greenwashing," where an investment product claims to be ESG compliant, but in name only (Asset Management Advisory Committee, 2021, p. 3). The draft summarized the current situation by stating: 
“...the lack of clear, consistent, and comparable issuer disclosure of material ESG matters may suggest a call to action, not inaction (Asset Management Advisory Committee, 2021, p. 5).”

The basic issue is that unlike financial performance, evaluating "sustainability" and similar issues does not lend itself to easy comparisons, especially with multiple organizations providing such evaluations using different benchmarks. The Draft concludes by encouraging more leadership from the SEC on defining objective considerations for ESG evaluation (Asset Management Advisory Committee, 2021).

\section{CURRENT POLITICAL CONSIDERATIONS}

ERISA fund fiduciaries must now contend with multiple conflicting pressures for investment decisions. As noted above, the pressure toward conservative investment objectives dates to the enactment of ERISA in 1974. However, social pressure in the United States (Zweig, 2021) and both social and regulatory pressure in other countries (Hughes-Jennett \& Polascheck, 2021) makes consideration of ESG and human capital issues a pivotal issue today. In the United States, the consideration of ESG, especially as related to "climate change," has become a major political issue (Jong, 2021).

\section{Trump Administration ERISA Rule}

The Department of Labor's (DOL) final rule, "Financial Factors in Selecting Plan Investments," was published on November 13, 2020, with an effective date of January 12, 2021. The conservative investment direction of this rule is clear from the opening explanation:

The final rule builds upon the core principles provided by the original investment duties regulation on the issue of prudence under section 404(a)(1)(B) of ERISA, at 29 CFR 2550.404a-1, which the regulated community has been relying upon for more than 40 years (Footnote omitted) (Financial Factors in Selecting Plan Investments, 2020).

Under this rule, plan fiduciaries may not sacrifice investment return or take on additional investment risk to consider non-pecuniary factors, nor can they subordinate the financial interests of plan participants and beneficiaries to other objectives. The Final Rule explains:

Each Interpretive Bulletin has consistently stated that the paramount focus of plan fiduciaries must be the plan's financial returns and providing promised benefits to participants and beneficiaries (Financial Factors in Selecting Plan Investments, 2020).

In other words, when companies are offering employees retirement funds to consider for investment, they must give preference to the financial performance potential of the fund. The Final Rule, addressing the growth of ESG investing, continues with:

Thus, each Interpretive Bulletin, while restating the "all things being equal" test, also cautioned that fiduciaries violate ERISA if they accept reduced expected returns or greater risks to secure social, environmental, or other policy goals (Financial Factors in Selecting Plan Investments, 2020).

With ESG investing growing more popular, the DOL under the Trump administration expressed concern about the lack of official definitions and standards for ESG factors (Financial Factors in Selecting Plan Investments, 2020). The Final Rule cites an OECD report, which summarizes the current situation with ESG investing in this manner: 
However, the lack of standardised reporting practices and low transparency in ESG rating methodologies limit comparability and the integration of sustainability factors into the investment decision process. The link between ESG performance and financial materiality is also ill-defined, with little evidence of superior risk-adjusted returns of ESG investments over the past decade (Organisation for Economic Cooperation and Development, 2020).

This gray area might lead employers to promote ESG-oriented funds to their employees through qualified retirement and savings plans which have factors unrelated to financial performance. The final rule requires plan fiduciaries to apply more scrutiny in selecting funds with non-pecuniary benefits and will require additional documentation of these factors to show how they might affect the risk of loss or opportunity for financial gain (Financial Factors in Selecting Plan Investments, 2020).

The apparent objective of the Trump DOL was that this rule would assist fiduciaries in carrying out responsibilities by avoiding decisions with investments based on non-pecuniary factors and protecting participants and beneficiaries' financial interests in their retirement benefits under the plans.

\section{Biden Administration ESG Considerations in ERISA Plans}

The Biden DOL announced on March 10, 2021, a non-enforcement policy for the final rule referenced above (Pelley \& Wechter, 2021). This is consistent with the new administration's indication of an interest in rejoining the Paris Climate Accord (Blinken, 2021), which the United States joined under the Obama Administration, but withdrew from it during the Trump Administration (Friedman, 2017). Such recent actions demonstrate that the new administration is friendlier to ESG-focused investment alternatives rather than the primarily financial approach of the prior administration.

The United States lags other countries, especially the European Union (EU), in pursuing ESG objectives (European Commission, 2021). While the EU has an aggressive implementation plan that may require some of the typical ESG approaches, rather than simply evaluating them, it remains to be seen if this will produce satisfactory financial results. Of course, if these steps are required through regulation, then reference to and evaluation of ESG factors would be mandatory, even if it did not produce the optimal financial outcome for various industries. In late 2020, a US SEC study was released that suggests establishment of consistent evaluation standards for ESG matters would be developed that would be more concrete than the current unregulated ESG evaluation system, but less specific than the EU standards referenced above (Asset Management Advisory Committee, 2020).

The main concern of the Biden administration was that the Trump era ERISA rule would have plan fiduciaries ignoring non-pecuniary ESG concerns with potential investment targets and only invest in the highest return on investment (Pelley \& Wechter, 2021). An Executive Order issued May 20, 2021, presents the rationale that:

The intensifying impacts of climate change present physical risk to assets, publicly traded securities, private investments, and companies - such as increased extreme weather risk leading to supply chain disruptions. In addition, the global shift away from carbonintensive energy sources and industrial processes presents transition risk to many companies, communities, and workers (Exec. Order No. 13990, 2021).

Such pronouncements do not yet establish that there actually are such financial risks or that they will likely occur in the near future. The termination of the Keystone Pipeline (Exec. Order No. 13990, 2021, Section 6) and other Biden administration efforts to make fossil fuels more expensive (Lambermont, 2021), have impacted the market already. The issue here is that these moves have actually favored certain existing industries. Astute and conservative investors and retirement plan managers may see this as a reason to focus on current and near-term financial performance, not ESG (Cheasty, 2019).

The Executive Order specifically addresses ERISA with the following section: 
Sec. 4. Resilience of Life Savings and Pensions. In furtherance of the policy set forth in section 1 of this order and consistent with applicable law and subject to the availability of appropriations, the Secretary of Labor shall:

(a) identify agency actions that can be taken under the Employee Retirement Income Security Act of 1974 (Public Law 93-406), the Federal Employees' Retirement System Act of 1986 (Public Law 99-335), and any other relevant laws to protect the life savings and pensions of United States workers and families from the threats of climate-related financial risk;

(b) consider publishing, by September 2021, for notice and comment a proposed rule to suspend, revise, or rescind "Financial Factors in Selecting Plan Investments," 85 Fed. Reg. 72846 (November 13, 2020), and "Fiduciary Duties Regarding Proxy Voting and Shareholder Rights," 85 Fed. Reg. 81658 (December 16, 2020) (Exec. Order No. 14030, 2021) (Napach, 2021);

The wording does not require that the DOL "suspend, revise, or rescind" the Trump DOL rule by September 2021, but it is highly likely that this will happen. This indicates that a modification of the instruction to ERISA plan administrators to move away from the Trump DOL approach and toward including ESG factors is a near certainty. Treasury Secretary Janet Yellen is even appointing a "climate czar" to oversee such changes (Davidson, 2021) (Kiernan, 2021).

\section{HOW SHOULD ERISA PLAN FIDUCIARIES ACT TODAY?}

A recent article from the CFA Institute underscores the positives and negatives of ESG investment considerations. The article reports on an extensive survey of 300 asset managers in the United States, United Kingdom, Germany and France. The results showed "very high priority" to "high priority" in ESG considerations in investing (Redding, 2021). However, the article cautions:

The first challenge that rang through loud and clear has to do with data. High-quality data on ESG corporate performance is critical, yet ESG measurement is still an evolving and imperfect science. Our survey showed that beneath the growing excitement and adoption around ESG approaches, there are still major gaps in the quantity and quality of the ESG information available to investors (Redding, 2021).

Even though the Trump-Era Final Rule is currently unenforced, fiduciaries must still be careful if they decide to offer funds based on non-pecuniary factors. They may be at risk of lawsuits claiming breaches of fiduciary duties. Legal issues may arise with following the current direction of the Biden DOL if fund managers focus too much on non-pecuniary ESG factors. The most definitive warning comes from the Biden Administration's SEC in April 2021 (U. S. Securities and Exchange Commission, 2021a). The SEC report summarizes the legal risks for fund managers as follows:

The staff noted, despite claims to have formal processes in place for ESG investing, a lack of policies and procedures related to ESG investing; policies and procedures that did not appear to be reasonably designed to prevent violations of law, or that were not implemented; documentation of ESG-related investment decisions that was weak or unclear; and compliance programs that did not appear to be reasonably designed to guard against inaccurate ESG-related disclosures and marketing materials (U.S. Securities and Exchange Commission, 2021a, p. 4).

ERISA was passed to help beneficiaries with their investments, and if a plan fiduciary nudges them towards an ESG fund that is not performing at market rates, problems may arise. In light of the pressure on 
ERISA plans to assure very long-term financial stability, this is apparently why the Trump DOL's final rule required strict scrutiny when considering non-pecuniary factors.

In a major article by Professors Schanzenbach and Sitkoff, they propose a possible approach that may allow consideration of ESG issues even in the current uncertain environment. They write:

We show that, in general, ESG investing is permissible for a trustee of a pension, charity, or trust subject to American trust fiduciary law if: (1) the trustee reasonably concludes that the ESG investment program will benefit the beneficiary directly by improving risk adjusted return; and (2) the trustee's exclusive motive for adopting the ESG investment program is to obtain this direct benefit (Schanzenbach \& Sitkoff, 2020).

As noted above, the challenge here is that it may be difficult under the current market circumstances, without widely accepted measurement standards for each element of ESG, to demonstrate that the trustees have met the burden in number 1, above. And, that they were not unduly influenced by personal ethical or social considerations under number 2 . The authors continue with a further definition of their approach:

First, we clarify the umbrella term "ESG investing" by differentiating it into two categories. We refer to ESG investing for moral or ethical reasons or to benefit a third party, what had been called SRI, as collateral benefits ESG. We refer to ESG investing for risk and return benefits - that is, to improve risk-adjusted returns - as risk-return ESG (Schanzenbach \& Sitkoff, 2020, p. 390).

The authors go on to note that "third party" benefit ESG investing would be a violation of the responsibilities of a fiduciary for a plan, but the "risk-return" ESG investing approach would be permissible (Schanzenbach \& Sitkoff, 2020). A comprehensive analysis of this article by Bernard Sharfman adopts much of the approach of Schanzenbach and Sitkoff, but rejects any investment based on a third party benefit approach as always being against the direction that should be taken by plan fiduciaries (Sharfman, 2020). $\mathrm{He}$ also argues that even a standard where ESG is considered from both perspectives could violate the obligations of plan fiduciaries because the focus should always be on the highest monetary return (Sharfman, 2020).

\section{CONCLUSION}

Based on the comments of the experts noted above, the prudent ERISA plan fiduciary should give strong consideration to the financial aspects of any plan investments. This would most likely mean ignoring the current actions of the Biden administration since these pronouncements may not provide a safe harbor for ERISA plan fiduciaries. At the same time, as ESG reporting continues to advance, it is likely that a consensus will form around certain parameters and it will become easier to consider ESG aspects for investments and to compare ESG evaluations for various investment alternatives in the future.

\section{REFERENCES}

Asset Management Advisory Committee. (2020, December 1). Potential Recommendations of ESG Subcommittee. U. S. Securities and Exchange Commission. Retrieved from https://www.sec.gov/files/potential-recommendations-of-the-esg-subcommittee-12012020.pdf

Asset Management Advisory Committee. (2021, July 7). Recommendations for ESG. U. S. Securities and Exchange Commission. Retrieved from https://www.sec.gov/files/amac-recommendations-esgsubcommittee-070721.pdf

Blinken, A.J. (2021, February 19). The United States Officially Rejoins the Paris Agreement. Press Release from Secretary of State Antony J. Blinken. 
Cheasty, G. (2019, November). Asset Management: Integrating ESG risk into a risk management framework. Deloitte Ireland. Retrieved from https://www2.deloitte.com/ie/en/pages/financialservices/articles/esg-risk-management-framework.html

CIGNA Corp. v. Amara, 563 U.S. 421. (2011).

Davidson, K. (2021, February 12). Yellen Is Creating a New Senior Treasury Post for Climate Czar. The Wall Street Journal. Retrieved from https:/www.wsj.com/articles/yellen-is-creating-a-newsenior-treasury-post-for-climate-czar-11613138479?mod=djem10point

Employee Retirement Income Security Act, 29 U.S.C. $§ \S 1001-1461$. (1974).

European Commission. (2021, July). A European Green Deal: Striving to be the first climate-neutral continent. European Commission. Retrieved from https://ec.europa.eu/info/strategy/priorities2019-2024/european-green-deal_en

Exec. Order No. 13990, 3 C.F.R. (2021). Retrieved from https://www.whitehouse.gov/briefingroom/presidential-actions/2021/01/20/executive-order-protecting-public-health-and-environmentand-restoring-science-to-tackle-climate-crisis/

Exec. Order No. 14030, 3 C.F.R. (2021). Retrieved from https://www.whitehouse.gov/briefingroom/presidential-actions/2021/05/20/executive-order-on-climate-related-financial-risk/

Fiduciary duties. 29 U.S.C. $\S 404(a)(1)(A)$.

Fifth Third Bancorp v. Dudenhoeffer, 573 U.S. 409. (2014).

Financial Factors in Selecting Plan Investments, 85 F.R. 72,846. (2020, November 13). (to be codified at 29 C.F.R. pts. 2509 \& 2550).

Friedman, L. (2017, June 1). Trump Serves Notice to Quit Paris Climate Agreement. The New York Times. Retrieved from https://www.nytimes.com/2019/11/04/climate/trump-paris-agreementclimate.html

Gurdus, L. (2021, May 9). ESG Investing to reach \$1 trillion by 2030, says head of iShares Americas as carbon transition funds launch. CNBC. Retrieved from https://www.cnbc.com/2021/05/09/esginvesting-to-reach-1-trillion-by-2030-head-of-ishares-americas.html

Hughes-Jennett, J., \& Polascheck, R. (2021, April 7). The EU's Increasing ESG Regulation and its Implications for Business. JD Supra. Retrieved from https://www.jdsupra.com/legalnews/the-eus-increasing-esg-regulation-and-7966413/

Jong, K. (2021, May 3). ESG in the Political Law Arena. JD Supra. Retrieved from https://www.jdsupra.com/legalnews/esg-in-the-political-law-arena-3061457/

Kiernan, P. (2021, April 19). U.S. Treasury Creates Climate Hub to Coordinate Policy. The Wall Street Journal. Retrieved from https:/www.wsj.com/articles/u-s-treasury-creates-climate-hub-tocoordinate-policy11618851657 ?cx_testId=3\&cx_testVariant $=$ cx_16\&cx_artPos $=1 \& \bmod =$ WTRN\#cxrecs_s

Kulesza v. New York University Medical Center, 129 F. Supp. 2 d 267. (2001).

Lambermont, P. (2021, July 16). Why Are Gas Prices Rising? The American Spectator. Retrieved from https://spectator.org/gas-prices-rising/

Loren v. Blue Cross \& Blue Shield, 505 F.3d 598. (2007).

Martin, C.C., \& Amert, A.S. (2017). Equitable Relief Under ERISA Following Amara. Employee Relations Law Journal, 43(3), 91.

McLeod Regional Medical Center v. Trustmark Life Insurance Company, 2010 U.S. Dist. LEXIS 156205. (2010).

Napach, B. (2021, May 21). Biden Orders DOL to End or Revise Rules Limiting ESG Investments. ThinkAdvisor. Retrieved from https://www.thinkadvisor.com/2021/05/21/president-biden-ordersdol-to-end-or-revise-rules-limiting-esg-investments/

Organisation for Economic Cooperation and Development. (2020). OECD Business and Finance Outlook 2020: Sustainable and Resilient Finance. OECD iLibrary. Retrieved from https://www.oecdilibrary.org/sites/eb61fd29-en/index.html?itemId=/content/publication/eb61fd29-en

Oringer, A.L., Rabitz, S.W., \& Zuber, A. (2020, November 12). An ESGplanation of ERISA's New Regulation on Social Investing. Dechert LLP. Retrieved from

156 Journal of Leadership Accountability, and Ethics Vol. 18(5) 2021 
https://www.dechert.com/knowledge/onpoint/2020/11/an-esgplanation-of-erisa-s-new-regulationon-social-investing.html?utm_source=vuture\&utm_medium=email\&utm_campaign=onpoint

Peirce, H.M. (2020, January 30). Statement on Proposed Amendments to Modernize and Enhance Financial Disclosures. Public Statement of Commissioner Hester M. Peirce.

Pelley, D.S., \& Wechter, K. (2021, March 16). Biden DOL Announces Non-Enforcement Policy on ESG Regulations. Arnold \& Porter. Retrieved from https://www.arnoldporter.com/en/perspectives/ publications/2021/03/biden-dol-announces-nonenforcement-policy-on-esg

Redding, R. (2021, July 13). ESG: Full Speed Ahead, with GPS. CFA Institute. Retrieved from https://blogs.cfainstitute.org/investor/2021/07/13/esg-full-speed-ahead-with-gps/

Schanzenbach, M.M., \& Sitkoff, R.H. (2020). Reconciling Fiduciary Duty and Social Conscience: The Law and Economics of ESG Investing by a Trustee. Stan. L. Rev., 72, 381.

Sharfman, B.S. (2020). ESG Investing Under ERISA. Yale J. on Reg. Bulletin, 38, 112.

U. S. Securities and Exchange Commission. (1999). SEC Staff Accounting Bulletin: No. 99 - Materiality. Retrieved from https://www.sec.gov/interps/account/sab99.htm

U. S. Securities and Exchange Commission. (2021a, April 9). The Division of Examinations' Review of ESG Investing. Risk-Alert from the Division of Examinations.

U. S. Securities and Exchange Commission. (2021b, October 12). SEC Response to Climate and ESG Risks and Opportunities. U. S. Securities and Exchange Commission. Retrieved from https://www.sec.gov/sec-response-climate-and-esg-risks-and-opportunities

Wooten, J.A. (2001). "The Most Glorious Story of Failure in the Business": The Studebaker-Packard Corporation and the Origins of ERISA. Buff. L. Rev., 49, 683.

Zweig, J. (2021, April 16). You Want to Invest Responsibly. Wall Street Smells Opportunity. Wall Street Journal. Retrieved from https://www.wsj.com/articles/you-want-to-invest-responsibly-wallstreet-smells-opportunity-11618586074 